Western University

Scholarship@Western

Management and Organizational Studies

Management and Organizational Studies

Publications

Department

$3-11-2011$

\title{
Token presence or substantive participation? A study of labor trustees on pension boards
}

Anil Verma

University of Toronto, verma@rotman.utoronto.ca

Johanna Weststar

Western University, weststar@uwo.ca

Follow this and additional works at: https://ir.lib.uwo.ca/mospub

Part of the Business Administration, Management, and Operations Commons, and the Work, Economy and Organizations Commons

Citation of this paper:

Verma, Anil and Weststar, Johanna, "Token presence or substantive participation? A study of labor trustees on pension boards" (2011). Management and Organizational Studies Publications. 25.

https://ir.lib.uwo.ca/mospub/25 
NOTE:

This is a pre-print version. The published article can be found at Journal of Labor Research 01/2011; 32(1):39-60

http://link.springer.com/article/10.1007/s12122-010-9101-6/fulltext.html

\title{
Token Presence or Substantive Participation? A Study of Labor Trustees on Pension boards
}

\author{
Anil Verma \\ University of Toronto \\ Johanna Weststar \\ Saint Mary’s University
}

\begin{abstract}
Even though worker representation on corporate boards remains elusive for most unions in North America, labor trustees sit on many pension boards. Using data from a survey of labor trustees to assess their participation in board activities, we find that labor trustees make greater contributions to procedure-based processes such as information sharing, rule-making and rule interpretation; and, fewer contributions to investment-based processes such as investment decisions, fund performance and manager selection. Longer tenure on the board appears to increase participation in procedure-based processes but not in investment-based issues. Gender does not seem to matter in explaining participation in board activities. Accountability in terms of a requirement to report back to their union did increase labor trustee contribution but only to procedural issues, not investment issues. Short board tenure, lack of multiple labor seats and lack of training appear to limit labor trustees' contribution to investment-based issues. Prior exposure to pension issues, and longer tenure appear to increase contributions to procedurebased issues. Exclusionary board dynamics hinder both types of contributions by labor trustees.
\end{abstract}


These findings point to areas in which labor representation on pension boards could be made more effective.

\section{Introduction}

It is by now old news that many employer-sponsored pension plans in North America, particularly defined benefit plans, are in a state of crisis due to underfunded liabilities. Unions have been fighting to gain more control of and protection over their members' pensions, a form of deferred compensation, for several decades. In Canada, public sector unions such as the Ontario Public Service Employees Union (OPSEU) have been leaders in negotiating and lobbying to bring more transparency and accountability to the governance and investment process of pension funds. A key method for gaining control was to obtain seats on the pension board of trustees for members of the pension plan itself, i.e., labor representatives. OPSEU gained joint trusteeship of their pension plan (the OP Trust) in 1994 and other unions soon followed either through direct collective bargaining or through changed legislation. Falconer $(1999 ; 17)$ reported that one-third of Canadian pension assets fell under joint-trusteeship; Carmichael \& Quarter $(2003 ; 22)$ noted that 18 of the top 23 unions in Canada had won or were in the process of winning some form of joint-trusteeship. A level of labor/member representation on all pension boards is currently legislated in the province of Quebec. Similarly, in the United 
States, legislation requires joint labor-management trusteeship in the Taft-Hartley pension plans that cover private sector unionized employees and Hess $(2005 ; 41)$ reported that one-third of public pension fund trustees in the US are member-elected trustees. Similar trends have been reported in the UK (Gribben \& Faruk 2004; Gribben \& Olsen 2002).

Some of the motivation behind this increase in member and/or labor representation on pension boards is part of the broader movement towards increased corporate social responsibility, accountability and transparency (Lin 1996). If comparisons can be made to the trusteeship of corporate boards, the appointment of independent outside directors/trustees (such as labor representatives) may be a mechanism for curbing managerial indiscretion and excess (Jensen 1993; Lipton \& Lorsch 1992; Minow \& Bingham 1993). Some of the motivation is perhaps due to the increasing pressure for decision-making bodies to be representative of their constituents (Sayce 2007; 2008). For unions and the workers they represent, the motivations also stem from the feeling that worker's capital in the form of pensions has been abused and misused by employers and financial elites. Unions see labor representation on pension board of trustees as a way to protect pensions in the future against the practices that caused the chronic underfunding of retirement benefits (i.e., contribution holidays, borrowing from the pension fund at low interest). Some also see a greater role for pension monies in bringing about a broader social unionist ideology to sustainably invest in workers and their communities. There is growing interest in the use of pension funds as vehicles of alternative investment using concepts such as the stakeholder's perspective, socially responsible investment, economically targeted investment, or the so-called, "triple bottom line" (Ambachtsheer 2005; Clark \& Hebb 2004; Fung et al., 2001; Ghilarducci 1992; Manley et al. 2005; OPSEU 2002(a); 2002(b); Salo 2005). Due to their size, pensions carry considerable financial clout. Anand $(2000 ; 46)$ assessed worldwide pension 
assets at \$11 trillion in 2000, a Freshfields report (2005; 6) estimated combined US and UK pension funds at $\$ 7.4$ trillion, and in the first quarter of 2006, trusteed pension funds in Canada had assets of $\$ 836.8$ billion (Quarter et al., 2008; xv).

The presence of labor trustees at the pension board table, however, does not necessarily result in changes to the board's decision-making and operational processes. In fact, very little is known about the role that labor trustees play in the day-to-day functioning of the pension board. Evidence from studies of worker representatives on both corporate boards ${ }^{1}$ and pension boards in the United States, Canada and the United Kingdom, discussed later in this paper, suggests that labor trustees might be marginalized on pension boards and therefore their actions may be limited or constrained to certain types of activities or functions. As such, this study is an empirical examination of contributions made by labor trustees to various board activities such as information dissemination, investment policy development, and interpretation of the pension trust deed. We use data from a new and unique survey of labor trustees who sit on Canadian pension boards and specifically examine whether factors such as trustee demographics, board structure and other subjective factors are associated with labor trustees' contributions to the board's procedure-oriented and investment-oriented activities. Two decades ago, Schuller and Hyman (1983) reported descriptive survey data on employee trustee contributions and industrial democracy and more recently Weststar and Verma (2007) reported qualitative data about the role of labor trustees on pension boards in Canada. To our knowledge the research reported here is the first to revisit and follow-up on this important work by examining labor trustee participation in a broad range of pension board activities using data from a survey of more than a hundred

\footnotetext{
${ }^{1}$ It is important to note that we recognize the inherent differences in operation and scope of corporate boards of directors versus pension boards of trustees. We draw on the research of worker representatives of corporate boards due to the relative lack of research on pension trusteeship. By using worker representation on corporate boards as a
} 
labor trustees. There are other recent surveys of member-elected trustees (Gribben \& Olsen, 2002) but they are focused on concerns such as socially responsible investment.

Briefly, using data from our survey we find that labor trustees' participation on the board is patterned in that they participate more in certain types of activities than others. In general, labor trustees report greater participation in procedural activities such as information dissemination to the members or trust deed interpretation than in investment-related activities such as the drafting of investment policy or selection of fund managers. Though we do not make normative judgments about the inherent value of each of these types of activity, we propose that the segregation of certain trustees from certain board tasks may be a hindrance to the overall effectiveness of governance and investment policies on pension boards. Marginalized or ineffective labor trustees would not be able to scrutinize board decisions from an independent perspective and thus bring a diversity of views to improve board governance.

\section{Definitions and Legislative Context}

A labor trustee, for our purposes, is a union member or retiree or their representative who holds a seat on a board that oversees the pension plan of current and former employees of a unionized workplace. In other words, a labor trustee is a constituent of an employer-sponsored pension plan that covers unionized workers. As such this definition, and hence this study, addresses a subset of the universe of all member-elected trustees. Member-elected trustees are representatives from the constituency of the pension fund, but they are not necessarily members of a union. It is possible that member-elected trustees have similar experiences, roles and patterns of activity as labor trustees as they are also the lay person on the board and may experience the tensions

comparator to labor representation on pension boards, we focus on the similarities of outsider status and perceived lack of expertise as opposed to duties and scope. 
between prudence and professionalism due to perceived or actual lack of expertise and experience (Kakabadse \& Kakabadse, 2004). From an industrial relations perspective, both nonunionized member-elected trustees and labor trustees would bring an employee perspective that is different from the perspective of employer trustees or other financial advisors. However, nonunionized member-elected trustees may have different perspectives and therefore act differently than labor trustees who would be connected directly to their own union, and more generally, to the broader labor movement. These connections would guide their behavior and actions within the board.

Labor trustees can come to pension boards in various ways. With the exception of those employees and industries that fall under jurisdictional authority of the federal government (i.e., Crown Corporations, banks, railways, and employees in the Yukon, Nunavut, and the North West Territories), pension funds in Canada fall under provincial jurisdiction and specific pension standards legislation. The regulations governing board composition also vary for public sector versus private sector plans as individual private sector unions have a greater range to negotiate pension issues through collective bargaining. The results are a wide array of governance structures across pension funds with and without member representation. In short, pension boards can be single or multi-employer, single or multi-union, and range from no member representation to joint-trusteeship. Labor trusteeship can be won through collective bargaining or legislation. For example, pension legislation in the province of Quebec requires that all trusteed plans have at least one pension trustee from active members and another from retirees.

Depending on the jurisdiction and union rules, labor trustees also come to their posts in a variety of ways. For example, they can be elected to their post by the general union membership, they can be appointed or selected by the union, they can be recommended by the union, but officially 
appointed by the government, or they can be recommended by the union but officially appointed by the employer. Despite this variance in selection method, most labor trustees have a history of being active in their union - sometimes even on pension and benefits committees - rather than being selected or elected as a raw recruit from the rank and file (Quarter, Carmichael and Ryan, 2008).

Overall, labor trusteeship seems to be most concentrated in the public sector in Canada. Indeed, some large private sector unions are resistant to the idea of union involvement in pension trusteeship (Weststar and Verma, 2007). The exceptions are in the province of Quebec due to their legislation and among private sector unions such as many building trades who have sole trusteeship over their plans. In the United States the pattern of labor trusteeship may be slightly different due to the legislation governing Taft-Hartley pension plans. Taft-Hartley plans are those that cover unionized workplaces in the private sector and can be single or multi-employer plans. They are required to have joint trusteeship with an equal number of labor and management trustees.

\section{Worker Representation on Corporate and Pension boards}

Due to the lack of previous research on labor trustees we look to another similar (but not the same) situation such as labor representation on corporate boards to gain some understanding of labor's role. In both situations, labor plays the role of an outsider with a potential clash of interest in contrast to other typical board members. Labor is also considered a non-specialist in financial and corporate decisions. One difference is that the actions of pension trustees are more constrained by legislation designed to protect the health of the plan (such as ERISA in the United States) than corporate boards or organizations as a whole. However, unions and pension activists 
would argue that the degree of capitalist power or influence is not so limited on pension boards. The Canadian Labour Congress has written that "the largely private nature of the investment process makes workers, communities and governments the hostages of those who control the investment process" (CLC, 1990: 3; as cited in Carmichael, Thompson \& Quarter, 2003) and an OPSEU policy paper on pensions reported that:

The values and belief structures of fund managers infuse their investment practices. Even though workers own the assets being managed, the workers who provided the capital have little say in what is done with their money. Investment decisions are made by a small, concentrated group of fund managers who decide where the money goes. They retain the privileges of capital through the exercise of proxy votes on decisions to purchase companies, on take-overs, on corporate policies including privatization and downsizing, on corporate behaviour such as health and safety and environmental standards, and finally on corporate structures and compensation (2002(a); 6).

Therefore, we argue that the struggle for legitimacy and influence faced by worker representatives on corporate boards, in practice, may be quite similar to the experiences of labor trustees on pension boards.

Research on worker representation on corporate boards, including employee stock ownership plans and pension boards, suggests that worker representatives or labor trustees are somewhat marginalized in their roles. Engelstad \& Qvale (1977) reported that the presence of worker representatives on German corporate boards did not dramatically effect how the board conducted business or made decisions. They reported that the activities of worker directors were limited to personnel issues and matters of working conditions and worker welfare. Similarly, research into worker directorships in Britain has concluded that the influence of worker directors (whether rank and file members or union officials), is limited to personnel and job security issues (Bank \& Jones, 1977; Brannen et al., 1976). Similar constraints have been predicted for outside directors on corporate boards under the managerial hegemony theory. These outside directors are not 
typical employees, but often CEOs or senior management from other organizations who have been appointed by the board. As Lin $(1996 ; 912)$ reported, "boards of directors are powerless to control abuses by management because the boards are inevitably controlled by management." Proponents of agency theory note that outside directors will be a benefit to corporate governance through increased transparency and accountability and alternative viewpoints. Arguing against this assertion, Lin (1996; 914-915) noted that outside directors may receive only selective information filtered through the CEO, they may not have the expertise to understand complex corporate decisions, and their schedules may not allow sufficient time to review board materials.

Hammer et al. $(1991 ; 664)$ studied the role definitions and role performance of worker directors to specifically determine whether these roles served as effective labor voice mechanisms. They concluded that "management prefers a limited role for the worker directors, one not threatening or diluting management's traditional power in decision-making." Worker directors, CEOs and worker constituents were presented with seven activities: express workers' views and concerns to management, protect the interests of workers, bring up workers' ideas and suggestions, explain board decisions to workers, justify management decisions to workers, influence policy decisions, and influence the way the company spends money (Hammer et al., $1991 ; 678)$. They were asked to comment on the role of the worker director in contributing to each activity. Hammer et al. found that CEOs emphasized the downward communication function (i.e., explaining board decisions to constituents after the decisions had been made) as the most important role of the worker director. They downplayed the "active labor advocacy role" (Hammer et al., 1991; 676) and said that expressing workers' views and concerns was the least important aspect of the worker director's role. On the whole, CEOs reported that worker directors did not contribute much to board debate or decision-making due to their lack of tenure 
on the board, lack of other experience and lack of relevant skills. Worker directors themselves reported that the representation and protection of worker interests was the most important facet of their role and felt that they could do more than they were in this area (Hammer et al., 1991; $672-673,676-677)$.

The few studies on the role of labor trustees on pension boards suggest similar compartmentalization of activities. The worker representation role risks marginalization through overt or covert actions of 'regular' or management trustees, due to lack of labor trustee expertise, and in the face of traditional interpretations of the fiduciary duty argument (Schuller \& Hyman, $1983 ; 1984)$. Based on interview data, Schuller and Hyman $(1984 ; 64)$ reported that the primary duty of labor trustees is information disclosure and this tends to focus on details of individual beneficiary concern rather than the strategic functioning of the fund or the financial reports. They note that labor trustees often serve only as watch-dogs and they can face official or de facto exclusion from relevant decision-making bodies. This lack of integration into the board culture or the unofficial board processes has also been noted in the case of British worker directors (Bank \& Jones, 1977; Brannen et al., 1976). Schuller and Hyman (1984; 64) reported that trustees (labor and otherwise) engage in "self-censorship" and withhold proposals or comment if the anticipated response in negative which adds to the a "culture of acquiescence". This 'board culture' of politeness and consent has also been reported with respect to corporate boards of directors (Jensen, 1993; Lin, 1996). Myners $(2001 ; 22,61)$ extended this point and argued that some trustees may be detrimentally uncritical of the assumed expertise of actuaries or fund managers because they themselves lack the professional experience in investing. Fund managers, advisors and the financial community have been reported as having a paternalistic attitude toward labor trustees (Carmichael \& Quarter, 2003; 23). As a result, labor trustees are likely 
regarded similarly to Hammer et al.'s (1991) worker directors. They are perceived as primarily disseminators of information by the fund managers and often by themselves, as opposed to participants in other aspects of the board such as deciding investment policy, monitoring fund performance and appointing fund advisors (Schuller \& Hyman, 1984).

\section{Participation of Labor Trustees in Pension board Activities}

Schuller and Hyman $(1984 ; 58)$ noted that pension trustees participate in six core areas of activity: 1) investment policy analysis and decisions; 2) monitoring fund performance; 3) selection of fund managers; 4) information sharing; 5) interpreting the pension rules; 6) applying or changing the rules/policies of the pension trust deed. We confirmed these through interviews with labor trustees and, after adding a seventh item (administrative duties), framed our survey around these activities. Drawing from the discussion above, we hypothesize that labor trustees will participate more in certain types of activities than others. Specifically,

H1: Labor trustees will contribute more to what we label 'procedural tasks' such as information sharing, interpreting the pension rules, and applying or changing the pension trust deed and less to 'investment tasks' such as investment policy analysis and decision-making, monitoring fund performance, and selecting fund managers.

Procedural tasks fit more closely with activities that labor trustees are likely to be familiar within their own union. These tasks may be also easier to learn. Investment activities, on the other hand, represent more foreign territory for the labor trustee who must move into the realm of pension control and governance, a role traditionally held by management and hired professionals from the financial community. At this point, we do not place any normative judgment on the relative importance or strategic value of either of these areas (either to the board as a whole or to the union). Both sets of activities can be important and/or strategic depending on the circumstances. 
There are a variety of factors that could influence whether labor trustees participate in procedural and investment activities. Regarding trustee expertise, Myners (2001) has proposed a Code of Conduct that encourages the professionalization of pension trustees and advocates for trustees with more informed backgrounds. He noted that 62 percent of his sample of UK-based trustees has no formal background in finance or investment. Kakabadse and Kakabadse (2004) have argued that 'lay trustees' operate very similarly to 'professional trustees' and have similar capacities to carry out their roles. With respect to the current study, it is hypothesized that labor trustees who have had more experience with pension issues prior to coming to the board will have a reduced learning curve and will contribute more to both procedural and investment activities. But we also hypothesize that labor trustees with longer tenure on the board will contribute more to investment activities because the new roles they need to learn would be well within their intellectual and cognitive capacity. As their tenure increases, labor trustees would likely have more access to at least some training (either through their union, the board, their employer, or on their own initiative), and they would likely become more confident and more comfortable in their role. Along these lines, we also hypothesize that labor trustees who report training needs in certain areas (see Data and Methods section below), would contribute less to those areas. Hence:

H2: Prior experience with pension issues will be positively related to contribution to procedural activities and investment activities.

H3: Board tenure will be positively related to contribution to investment activities.

H4: Need for training in specific areas will be negatively related to contribution levels to the areas of identified training need.

Though labor trustees on Taft-Hartley boards in the US and some public sector boards in Canada enjoy joint trusteeship, many labor trustees find themselves to be in the minority on a 
board. Even within some joint trusteeship boards, labor trustees from a single union would be reduced to a minority if there are multiple unions with divergent views. By virtue of their worker and union status and their relatively new presence on the board, labor trustees are like a minority group struggling for recognition. As it has been the case, historically, for equity seeking groups such as women, racial and ethnic minorities, religious minorities, people with disabilities, LGBTQ groups, it often takes a critical mass to have some impact on policymaking. A single 'alternative' representative on the board is usually not enough to trigger a change in norms, attitudes and behaviors. Based on these considerations, we hypothesize that labor trustees will contribute more to board activities if they sit on boards with a higher percentage of other labor trustees. Based on the minority status argument, we also hypothesize that female labor trustees may be in a situation of double jeopardy where they are encouraged into procedural over investment roles because of both their sex and their labor affiliations ${ }^{2}$.

H5: Percentage of labor trustees on the board will be positively related to contribution to procedural and investment activities.

H6a: Being female will be positively related to contribution to procedural activities and negatively related to investment activities.

There is a large literature about role ambiguity and the negative impacts it has on job performance (see Bedeian \& Armenakis, 1981; Fisher \& Gitelson, 1983; Jackson \& Schuler, 1985). There is not sufficient space to detail those arguments here, but it has been suggested that labor trustees could face a degree of role ambiguity. Weststar and Verma $(2007 ; 2008)$ noted that there does not seem to be a clear consensus among unions or labor trustees as to their precise purpose and role at the board. Many feel that they should fulfill their fiduciary mandate and essentially operate as would any other pension trustee. Others feel that the purpose of the labor

\footnotetext{
${ }^{2}$ A hypothesis about ethnicity was not included because the sample contained only a very small number of visible minorities (see Table 1). Similarly, language was not included as all trustees who answered the survey in either
} 
trustee is to meet their fiduciary role, but to also question and challenge the status quo of pension governance. In this way, some unions, labor trustees and other pension fund reformers would see labor trustees push for alternative investment policies and exercise greater shareholder activism. Though many labor trustees are asked to 'leave their union hat at the door' (Weststar and Verma, 2007, 400), some unions have defined agendas and more developed accountability mechanisms.

It is likely that labor trustees operating in these environments would be more engaged in both procedural and investment activities than trustees with no or little guidance or agenda.

H7: Requirements to report back to the union will be positively related to contribution to both procedural and investment activities.

H8: Helpful guidelines from the union will be positively related to contribution to both procedural and investment activities.

The factors discussed above are fairly objective measures of trustee, board and union characteristics. Given the earlier discussion about the experiences of worker representatives on corporate and pension boards, it is also important to address a more subjective factor. As noted by Carmichael, Thompson \& Quarter (2003), Hammer et al., (1991), and Schuller and Hyman (1984), worker representatives/labor trustees often find themselves in an unsympathetic and somewhat foreign environment. Exclusionary rules and procedures, norms of the board, board politics and other subjective factors all act to potentially constrain the activities of labor trustees. Therefore we hypothesize that:

H9: Perception of exclusionary board dynamics will be negatively related to contribution to all activities: procedural and investment-related.

\section{Data and Methods}

The research presented here is based on data from a survey of labor trustees in Canada that was administered over the web and in paper form during 2004-05. The target population was labor 
trustees, and therefore, trusteed pension plans. Since a comprehensive directory of labor trustees in Canada could not be found, our survey sample was constructed through a combination of methods including snowball sampling from known trustees, flyers at pension conferences, survey distribution at labor trustee training sessions, survey links posted on resource websites for labor trustees, and cold calling of both trustees and fund administrators using contact information obtained through internet searches and pension fund directories. These efforts produced a list of 231 labor trustees and 116 usable surveys. This is a response rate of fifty percent for the sample population. ${ }^{3}$ These 116 responses represent 74 unique pension funds and 45 unique unions, covering a broad range of pension funds and unions within the niche of large, defined-benefit plans in the public sector. This is described in detail below. An overview of the sample demographics is presented in Table 1.

Determining the representativeness of this sample is somewhat problematic. It is difficult to locate labor trustees in Canada because no single institution, including Statistics Canada or labor federations such as the Canadian Labour Congress, maintains a comprehensive directory of all labor trustees or even a count of their presence on boards ${ }^{4}$. As well, government reports on pensions often present overviews of information about all registered pension plans and not of trusteed plans separately. Therefore it is difficult to determine a precise count and demographic profile of the target population.

\footnotetext{
${ }^{3}$ There are caveats to this number. It may be an underrepresentation because some of the 231 were not contacted directly by the researchers but rather through their union or the pension fund. Therefore, some may not have received adequate notification of the survey. This would decrease the survey population and therefore increase the final response rate. On the other hand, it is likely that other trustees heard about the survey, but did not complete it. This would increase the survey population and therefore decrease the final response rate. It was not possible for us to estimate these numbers. In general, we can see no pattern of non-response. In one case a labor trustee declined to participate because the administrators of her pension plan told her not to participate. This 'participation ban' also included 7 other labor trustees from that particular board. However this was a public sector board and we have ample representation from that sector and other labor trustees from the unions represented by those trustees.
} 
At the time of our data collection, there were over 14,000 registered pension plans (RPPs) in Canada. Public sector plans represent $8 \%$ of the total, but over $50 \%$ of the total RPP plan members and over 60\% of the total RPP plan assets (Statistics Canada, 2003(a); 2003(b); 2009). Two-thirds of the public sector RPPs are large plans while the majority of RPPs in the private sector are small plans. Most large plans are in the public sector. The majority of all RPPs are defined-benefit plans (84\%) while 14\% are defined-contribution and the remainder are hybrid models. The majority of defined-benefit plans are found in the public sector and defined-benefit plans have the most members. Large RPPs in Ontario and Quebec represent the most members ( $40 \%$ and $24 \%$ respectively). Of all the RPPs in Canada, the largest sub-group is trusteed pension plans. About 4000 plans cover about $70-80 \%$ of all workers with RPPs and about $75 \%$ of all assets in RPPs.

To sum up, the RPP landscape in Canada is dominated by large, public sector, definedbenefit plans with trust agreements. Given the leading charge of public sector unions for labor trusteeship and from anecdotal information and previous interviews with labor trustees we can assume with a fair degree of certainty that most labor trustees in Canada are older white males who sit on large, public sector, defined-benefit plans. If this were the case, then our sample would be quite representative of this group. Our sample's greater limitation is size. If roughly one-third of trusteed plans have labor trustees (Falconer, 1999), the target population would be 1,300 funds. Our sample then represents approximately $5 \%$ of that number.

\section{Dependent and Independent Variables}

\footnotetext{
${ }^{4}$ The Canadian Pension Fund Directory (available at www.investmentreview.com) provides basic contact and financial information on the largest 1,500 plans at a considerable cost but does not identify trustees by name, address and affiliation.
} 
We constructed dependent variables for our analyses based on the notion that labor participation in all board decisions will not be equally uniform. Based on the discussion above, we subjected the seven items drawn from Schuller and Hyman (1984) and previous interviews, to a factor analysis procedure using the maximum likelihood (ML) option and employing oblique rotation to allow for the possibility of correlated factors (Costello \& Osborne, 2005). Using multiple measures of statistical fit (Conway \& Huffcutt, 2003), and harmonizing with our expectations, a two-factor solution was deemed to be the best fit of the data ${ }^{5}$. The item relating to general administrative duties was dropped as it did not load sufficiently with either factor and generally received low response rates from the trustees who completed the survey. This is likely because larger funds tend to have significant numbers of support staff who carry out these duties related to fund activities. Factor one was labeled 'investment-based contributions' which includes the following three items: investment policy analysis and decisions, monitoring fund performance, selection of fund managers. Factor two was labeled 'procedure-based contributions' which includes the following three items: information sharing, interpreting the pension rules, applying or changing the rules/policies of the pension trust deed. To arrive at a final factor score, the individual items for each factor were added and averaged resulting in a range of $0-4$ where 0 indicates no contribution and 4 is a very high contribution. Table 2 shows the factor loadings and Cronbach's Alpha scores for combining individual items into each factor. By averaging items within each factor we have implicitly assigned equal weighting to each item within the factor.

\footnotetext{
${ }^{5}$ Two-factor fit statistics: $\mathrm{RMSEA}=0.00,90 \% \mathrm{CI}=0.0-0.13 ; \chi^{2}=3.13, \mathrm{p}=0.66$ One-factor fit statistics: $\mathrm{RMSEA}=0.21,90 \% \mathrm{CI}=0.16-0.27 ; \chi^{2}=51.40, \mathrm{p}=0.0$ A three-factor model was also tested, however none of the items loaded strongly on the third factor so this option was disregarded.
} 
The independent variables for the hierarchical regression are based on the hypotheses discussed earlier. To measure previous expertise, survey respondents were asked: "What was your exposure to pension issues before becoming a labor representative on this fund?" They were asked to check any of the following as applicable: previous member of a pension body, labor education, other courses, on-the-job training, self-study, other experience with pension issues (i.e., negotiating or own pension issues). These options were condensed into a dichotomous measure of prior exposure with 0 indicating that the trustee had checked none of these sources and 1 indicating that they had checked one or more.

Board tenure was included as a set of three dummy variables. Level one included respondents who were in their first year $(<1 \mathrm{yr})$ and this was used as the omitted reference group. Since the average length of a trustee term in our sample was 3 years, level two was set to include respondents who were in the midst of their first term ( $\geq 1$ and $<4 \mathrm{yrs})$. Level three included respondents who were in their second term or beyond ( $\geq 4 \mathrm{yrs})$. This segmentation scheme was chosen rather than leave the variable as continuous because the responses dropped off significantly beyond the first term ( 3 years) and it was assumed that there would be a significant difference between trustees who have had multiple terms on the board versus those who were just starting out.

Training need was included as a set of dichotomous (dummy) variables for each of the seven training areas: 1) fiduciary responsibility, 2) pension law, 3) capital markets/investment strategy, 4) pension issues from a labor perspective, 5) application of social/economic criteria to investment decisions, 6) actuarial valuation, and 7) pension benefits. Respondents were asked to rate $(1=$ strongly disagree to $5=$ strongly agree $)$ whether they needed training in each of those areas. Responses of strongly agree, agree were coded as needing training (coded 1) while 
strongly disagree, disagree and neither agree nor disagree were coded as not needing training (coded 0$)$.

There are two variables that measure different aspects of minority status. Percent union is a continuous variable constructed from two separate survey questions. It denotes the percentage of labor trustees on the board relative to the entire board. Female is a dummy variable denoting biological sex where male is coded as 0 and female as 1 . We considered including language (French or English), however on further inspection there were no respondents who serve on boards that function outside of their dominant language (i.e., all respondents who answered the survey in French sit on boards operating in Quebec) ${ }^{6}$.

Three variables measure the linkages between the labor trustee and their union. The first two, 'report exec' and 'report members' measure the frequency of reporting back to each of these groups (not at all $=0$, annually $=1$, semi-annually $=2$, at least quarterly $=3$ ). The second variable, 'guidelines', is a dichotomous measure of the guidelines that trustees receive from their unions. Respondents were asked whether they would rate the guidelines that they receive as: poor, minimal, adequate, good, excellent, or if they received no guidelines at all. Ratings of zero, poor or minimal guidelines were grouped and coded as 0 . Ratings of adequate, good, or excellent guidelines were coded as 1 .

The last independent variable measures the degree to which labor trustees perceive and are impacted by exclusionary board dynamics. The PEBD (perceptions of exclusionary board dynamics) variable is composed of four separate items (each a 5-point Likert-type scale): 1) I often feel excluded from in-depth policy discussions; 2) Most substantive decisions are made within the meetings (reverse coded); 3) I do not get enough information from the pension staff;

\footnotetext{
${ }^{6}$ Visible minority status was also included but not used in our analysis because there were very few self-identified visible minorities in our sample.
} 
4) The meetings seem to rubber-stamp decisions that are made elsewhere. Cronbach's Alpha for these combined items is 0.83 .

The descriptive statistics for the dependent, independent and control variables (province, sector, plan type, and plan asset size) as well as correlations are presented in Table 3. Results from the regression analyses are presented in Table 4. The independent variables were added to the regression in three steps. The first step, Model One, contains only control variables. Model Two includes the independent variables that measure demographic characteristics of trustees and key structural characteristics of the pension board or union. Model Three includes the last independent variable - the more subjective perception of exclusionary board dynamics (PEBD). The effects of this last variable should be interpreted with some caution given its subjective nature. It is measured at the same time as the self-report measures of personal contribution to investment-based and procedure-based activities. Though statements of causality are always problematic with any cross-sectional dataset, these particular outcomes should be considered even more carefully as associations and indicators of complex and interwoven relationships. Given the exploratory nature of research on labor trustees and the potentially large impact that issues of board dynamics may have, we feel that it is important to highlight and discuss these potentially significant associations.

\section{Results and Discussion}

According to the mean values of each factor presented in Table 3, labor trustees contribute somewhat less to investment-based activities than procedure-based activities. Fitting with this result, one trustee reported in the open comments section of the survey that he would like to see "more time devoted to strategy versus handling of routine business." Another noted, "I focus 
time on areas where I can make the most difference, like administration and the big picture, because my term is only three years so I don't have time to get up to speed on the more complicated stuff like investments." He went on to say that he "doesn't even bother with training in that area." These results support Hypothesis 1 .

Regression results are presented in Table 4. Hypothesis 2 is partially supported: prior exposure to pension issues before joining the board is positively and significantly related to procedure-based contributions, but not investment-based contributions. This actually corresponds with the qualitative comments noted above and fits with labor trustees' prior experience which may involve interpreting their own pension details, serving on a pension and benefits committee at the workplace, or negotiating contribution levels in collective bargaining. All of these activities deal with procedural issues rather than investment-related issues. As well, most labor trustees in our sample had prior experience serving their union in some capacity before their appointment/election to the board. These experiences would also be in the areas of administering a collective agreement and other union functions which would correspond more closely to the procedural tasks of a pension trustee.

It was hypothesized that tenure on the board would allow labor trustees to move beyond their initial strengths or comfort areas into new territory, however Hypothesis 3 was supported only partially: board tenure becomes significantly and positively related to procedure-based contributions as trustees gain more experience, but not to investment-based contributions for either recently-appointed trustees or even for trustees with longer tenure. The procedural contributions of labor trustees who are in their second or third year are no different from those in their very first year on the board. This corroborates the steep learning curve of labor trustees noted by our respondents and mentioned in other studies (Weststar and Verma, 2007). However, 
when trustees acquire four or more years on the board their contribution is significantly higher compared to their first year in office. On the other hand, the lack of relationship with board tenure and investment-based activities suggests that the trustee is excluded from these activities - either by their own choice as the comment above illustrates, or due to other factors such as exclusionary dynamics within the board (discussed more below). However, it should be pointed out that trustees may choose to focus their time on activities that are of specific importance to their constituents and their union. Experienced labor trustees may see their procedural tasks as more useful or beneficial to their constituents or their union. For example, a change in the fund rules may result in a change in benefits or governance that is more salient to the union than the selection of a fund manager. However, a narrow focus on procedural tasks, whether voluntary or involuntary, is arguably more limited in scope and time than directing the investment policy of the fund itself. Under these conditions, the labor trustee can not be expected to 'grow' into new roles such as investment-related tasks.

In the second step of the regression, the need for training in the application of SRI and ETI concepts to investment decisions is found to be negatively and significantly associated with investment-based contributions. This relationship becomes insignificant in the third step of the model when perceived exclusionary board dynamics is included. Therefore, there is partial support for Hypotheses 4. It is often assumed that labor trustees would support more alternative investment strategies irrespective of their knowledge of the subject matter. However, a negative relationship between their involvement in investment-based activities and their perceived need for training in these alternative investment options (SRI, ETI, etc.) suggests that labor trustees would participate more if they perceive that they have adequate knowledge and less if they feel that they need more training. 
In case of the variable, 'percent union', a similar result occurs for Hypothesis 5 which is partially supported. In the second step of the regression analysis higher percentages of labor trustees on the board is positively and significantly related to investment-based contributions, but this association becomes insignificant in step three. It is likely easier to bring forth alternative viewpoints from an equal or majority position than one of minority. With more labor trustees on the board, these viewpoints are less likely to be subject to the constraining influence of non-labor trustees such as the official or de facto exclusion from relevant decision-making bodies, or the lack of integration into the board culture or unofficial board processes noted earlier (Bank \& Jones, 1977; Brannen et al, 1976; Schuller \& Hyman, 1984).

To understand why these two variables, need for training in SRI/ETI and percent union, become insignificant in the third step, it is necessary to jump ahead to Hypothesis 9. This hypothesis is fully supported by the results: labor trustees who perceive a higher level of exclusionary board dynamics are less likely to contribute to both activities - investment-related and procedural. The effect is larger for investment-based activities compared to procedural ones (56\% versus $25 \%)$. This finding resonates with Hammer et al.'s $(1991 ; 676)$ finding that CEOs prefer worker directors to engage in activities of downward communication only (i.e., procedural activities). These actions receive more support and therefore are less hindered by perceptions of exclusionary board dynamics.

In both cases, these are some of the larger effects in the models tested. Therefore it is possible that perceived exclusionary board dynamics is capturing the variance in the need for training in alternative investment strategies and the percentage of labor trustees on the board. It is arguably within these frameworks - where labor trustees are lacking the confidence, the expertise, or the numbers to strongly bring forward alternative investment viewpoints - that they 
would be most susceptible to perceptions of exclusion due to traditional board norms. To examine further this possibility we performed a post hoc mediation analysis (Baron \& Kenny, 1986). The need for training in SRI/ETI was positively and significantly associated with perceptions of exclusionary board dynamics $(\mathrm{b}=.42, \mathrm{p}<.01)$ and the relationship between need for training in SRI/ETI and contribution to investment-based activities became non-significant once the PEBD variable was included. The mediation test failed for percentage of labor trustees on the board - the relationship between percentage of labor trustees and PEBD was non-significant. So, we have partial support for the notion that exclusionary dynamics within the board are playing a role in limiting full participation of all trustees. It is also possible that the test failed in the case of percentage of labor trustees due to the relatively small sample size. Further analysis with a larger dataset could confirm and further refine these findings.

Hypotheses 6 and 8 were not supported: there appears to be no difference in the contribution levels of male versus female labor trustees and the quality of the guidelines from the union are not associated with contribution levels. Hypothesis 7 is partially supported: labor trustees who report back to their union executives report higher contribution levels to procedure-based tasks, but not to investment-based tasks. This finding supports the interpretation raised earlier (Hypotheses 2 and 3) that procedure-based issues may be of more direct relevance or interest to the union than investment-based issues. Indeed, it could be argued that most unions are first and foremost interested in protecting and improving upon the pensions of their members, while only a handful of unions have taken up the larger banner of pension investment activism. As such, most union accountability mechanisms would reinforce activity in procedure-based areas.

\section{Conclusions}


Unions across the industrialized world are succeeding, even if modestly, in their attempts to gain a voice for labor through worker representation on pension boards. However, our data suggest that these voices are marginalized in the policymaking process for a variety of reasons. Labor trustees on pension boards are most likely to contribute to procedural areas of board activity such as information sharing, interpreting the rules of the trust deed, and changing rules or policies. Labor trustees make fewer contributions to the investment-related aspects of fund governance such as interpreting, analyzing and writing the investment policies, monitoring fund performance, reviewing the performance of fund managers and participating in the selection of new ones. The good news from our survey is that gender did not seem to matter in explaining participation in board activities. We do find that trustees required to report back to their union participated more actively, but their participation was still limited to procedural issues and did not extend to investment issues.

The analyses conducted here suggest that labor trustees are being steered in the direction of these procedural activities due to a variety of factors. First, labor trustees tend to have past experience with pension issues (and also anecdotally with union business) and they more naturally take up the trustee tasks that resemble those prior experiences. Second, the majority of unions (and therefore their trustees) may focus on a more traditional interpretation of pension involvement that focuses on the administration of the fund. These unions are used to interacting with pension funds through traditional arms length bargaining exercises and this tendency may carry on even when the gap is closed with a labor seat on the pension board. As such, labor trustees will direct their efforts to issues of deficit and surplus, internal governance of the plan, transparency, contribution levels and the administration of monies to plan members. Despite broad claims from some unions, academics and pension activists that seats on pension boards 
will claim control over workers' capital and redefine investment ideology to the benefit of workers and their communities, this research indicates that most labor trustees are operating within a very narrow and traditional role.

On the issue of developing a uniquely labor voice among worker representatives on corporate boards, Hammer et al. $(1991 ; 666)$ argue that if conventional board directors and corporate management are the first to define the role for worker directors, they would influence the cognitive schema of worker directors such that their role is framed in a way that does not oppose traditional boundaries. Hammer et al. $(1991 ; 672-677)$ go on to suggest that the workforce constituency has the opportunity to shape this role more as a labor voice if they are involved in the early selection, training and direction of their member directors. In light of the analyses presented here, the same conclusions could be made for labor trustees and their unions. If it is the goal of unions to expand beyond their traditional relationship with capital and pensions, it is important for unions to be clearly involved at the start of a labor trustee's development. This will help to ensure that labor trustees can define their role as an active and alternative voice in all aspects of the pension fund and give them the tools to follow through with this role definition. As such, the labor trustees will be less susceptible to the covert or overt pressures, norms, isolation, or feelings of inability that encourage them to assume more traditional procedural roles and potentially become marginalized members of the board. In addition, the potential benefits of board diversity (Sayce, 2008) will not be realized if the diverse groups are not full and active participants.

Lastly, some limitations of this study should be noted. For one, the sample is small and it represents, primarily, large, defined-benefit, trusteed plans in the public sector. As well, we have no baseline for pension trustee activity in general. This research provides a within-group 
snapshot of the experiences of labor trustees and does not attempt to compare them to other pension trustees (Kakabadse \& Kakabadse, 2004). It is possible that non-labor trustees would report similar contribution patterns given the expertise of fund managers, constraints from regulatory legislation or other factors. However, comments made in the qualitative section of our survey, anecdotal evidence through conversation with labor trustees and other research (Weststar and Verma, 2007; Schuller \& Hyman, 1983; 1984) indicate differences in treatment and activity. Useful further research would be to assess the actions of all pension trustees to be able to compare three broad groups: employer trustees, unionized member trustees, and non-unionized member trustees.

This research focused on the micro-level issues of the demographic, structural, and psychological factors associated with labor trustee contribution to pension board activity. Another fruitful direction of future research is to connect research on pension board trustees with pension board performance. There has been some research to this end with corporate boards and firm performance (i.e., Baysinger \& Butler, 1984; 1985; Hermalin \& Weisbach, 1991) and some aggregate research relating board composition and labor trustee tenure to performance (Hess, 2005). Ultimately for the development of corporate governance and the increased acceptance of worker involvement in corporate decision-making, it is important to more completely understand the complexity of the link between worker or labor trustees (and board diversity in general) and pension fund performance. As well, longitudinal data that traces a trustee's development, contribution levels and feelings toward integration and board dynamics from their pre-role preparation through multiple terms on the board would greatly assist our understanding of the impact of worker representation on pension boards. 


\section{References}

Ambachtsheer, J. (2005). 'Socially responsible investing'. Benefits and Compensation International, 35 (1): 36-43.

Anand, V. (2000). 'U.S. pension assets cross $\$ 10$ trillion'. Pensions and Investments, March 20: 46.

Bank, J. and Jones, K. (1977). Worker-Directors Speak, Westmead: Gower.

Baron, R. M. and Kenny, D. A. (1986). 'The moderator-mediator variable distinction in social psychological research: conceptual, strategic and statistical considerations'. Journal of Personality and Social Psychology, 51 (6): 1173-1182.

Baysinger, B and Butler, H. (1984). 'Revolution versus evolution in corporation law: the ALI's project and the independent director'. George Washington Law Review, 52 (2): 557-581.

Baysinger, B. and Butler, H. (1985). 'Corporate governance and the board of directors: performance effects of changes in board composition'. Journal of Law, Economics and Organization, 1 (1): 101-124.

Bedeian, A. G. and Armenakis, A. A. (1981). A path analytic study of the consequences of role conflict and ambiguity. Academy of Management Journal, 24: 417-424.

Brannen, P., Batstone, E., Fatchett, D. and White, P. (1976). The Worker Directors: A Sociology of Participation. London: Hutchinson.

Carmichael, I., Thompson, S. and Quarter, J. (2003). 'Transformative Education for Pension Fund Trustees'. Canadian Journal for Studies in Adult Education, 17(1).

Carmichael, I. and Quarter, J. eds. (2003). Money on the Line: Workers' Capital in Canada. Toronto: Canadian Centre for Policy Alternatives.

Clark, G. L. and Hebb, T. (2004). 'Pension fund corporate engagement: the fifth stage of capitalism’. Relations Industrielles/Industrial Relations, 59 (1): 142-171.

Conway, J. M. and Huffcutt, A. I. (2003). 'A review and evaluation of exploratory factor analysis practices in organizational research.' Organizational Research Methods, 6 (2): $147-168$.

Costello, A. B. and Osborne, J. W. (2007). Best practices in exploratory factor analysis: Four recommendations for getting the most from your analysis. Practical Assessment, Research and Evaluation, 10(7). 1-9.

Falconer, K. (1999). Prudence, Patience and Jobs: Pension Investment in a Changing Canadian Economy. Ottawa: Canadian Labor Market and Productivity Centre. 
Fisher, C. D. and Gitelson, R. (1983). A meta analysis of the correlates of role conflict and ambiguity. Journal of Applied Psychology, 68: 320-333.

Freshfields Bruckhaus Deringer. (2005). A Legal Framework for the Integration of Environmental, Social and Governance Issues into Institutional Investment. Geneva, Switzerland: Asset Management Working Group, United Nations Environmental Programme Finance Initiative.

Fung, A., Hebb, T. and Rogers, J. eds. (2001). Working Capital: The Power of Labor's Pensions. Ithaca, NY: Cornell University Press.

Ghilarducci, T. (1992). Labor's Capital: The Economics and Politics of Private Pensions. Boston: MIT Press.

Gribben, C. and Faruk, A. (2004). Will UK Pension Funds Become More Responsible? A Survey of Trustees. London: Just Pensions and UK Social Investment Forum.

Gribben, C. and Olsen, L. (2002). Will UK Pension Funds Become More Responsible? A Survey of Member Nominated Trustees. London: Just Pensions and UK Social Investment Forum.

Hammer, T., Currall, S. and Stern, R. (1991). 'Worker representation on boards of directors: a study of competing roles'. Industrial and Labor Relations Review, 44 (4): 661-680.

Hermalin, B. E. and Weisbach, M. S. (1991). 'The effects of board composition and direct incentives on firm performance'. Financial Management, 20 (4): 101-112.

Hess, D. (2005). 'Protecting and politicizing public pension fund assets: empirical evidence on the effects of governance structures and practice'. U.C. Davis Law Review, 39 (1): 187-224.

Jackson, S. E. and Schuler, R. S. (1985). A meta analysis and conceptual critique of research on role ambiguity and role conflict in work settings. Organizational Behavior and Human Decision Processes, 36: 16-78.

Jensen, M. C. (1993). 'The modern industrial revolution, exit and the failure of internal control systems.' Journal of Finance, 48 (3): 831-880.

Kakabadse, N. K. and Kakabadse, A. (2004). 'Prudence vs professionalism: exploratory examination of pension trustee capability'. Personnel Review, 34 (5): 567-587.

Lin, L. (1996). 'The effectiveness of outside directors as a corporate governance mechanism: theories and evidence'. Northwestern University Law Review, 90 (3): 898-976.

Lipton, M. and Lorsch, J. W. (1992). 'A modest proposal for improved corporate governance'. Business Law, 48: 59. 
Manley, K., Hebb, T. and Jackson, T. (2005, June 3-5). 'Pension fund investment in underserved capital markets: implications for Canadian policy makers'. Canadian Industrial Relations Association Annual Meeting, London, ON.

Minow, N. and Bingham, K. (1993). 'The ideal board'. Corporate board, 18 (July-Aug): 11.

Myners, P. (2001). Institutional Investment in the United Kingdom: A Review. Retrieved March 4, 2009 from http://www.hm-treasury.gov.uk/d/31.pdf.

OPSEU. (2002a). OPSEU Policy Statement with respect to Union Appointed Trustees and Sponsors for Jointly Trusteed Plans. http://www.opseu.org/benefit/PolicyReport.pdf.

OPSEU. (2002b). OPSEU Policy Statement with respect to Union Appointed Trustees and Sponsors for Jointly Trusteed Plans: Recommendations. http://www.opseu.org/benefit/recommendations.htm

Quarter, J., Carmichael, I. and Ryan, S. eds. (2008). Pensions at Work: Socially Responsible Investment of Union-Based Pension Funds. Toronto, ON: University Of Toronto Press.

Salo, J. (2005, October 14-15). 'Shareholder activism, social and environmental standards: an analysis of recent trends from annual general meetings 2001-2004'. Pensions at Work Conference, Toronto, Ontario.

Sayce, S. (2007, September) 'Being a Female Pension Trustee'. International Industrial Relations Conference, Manchester, UK.

Sayce, S. (2008, July) 'Diversity in Pension Trusteeship'. International Employee Relations Association Conference. Nijimingen, Netherlands.

Schuller, T. and Hyman, J. (1983). 'Information, participation and pensions: Strategy- and employee-related issues'. Personnel Review, 12 (3): 26-30.

Schuller, T. and Hyman, J. (1984). 'Forms of ownership and control: Decision-making within a financial institution'. Sociology, 18 (1): 51-70.

Statistics Canada. (2003a). 'Canada's Retirement Income Programs: A Statistical Overview 1990-2000'. Catalogue \#: 74-507-XIE http://dsp-psd.pwgsc.gc.ca/Collection-R/Statcan/74-507-XIE/0010074-507-XIE.pdf

Statistics Canada. (2003b). 'Pension Plans in Canada. Pension and Wealth Research Paper Series'. Catalogue \#: 13F0026MIE2004001. http://dsp-psd.pwgsc.gc.ca/Collection/Statcan/13F0026M/13F0026MIE2004001.pdf

Statistics Canada. (June 8, 2009). 'Pension Plans in Canada. The daily'. http://www.statcan.gc.ca/daily-quotidien/090608/dq090608c-eng.htm 
Weststar, J. and Verma, A. (2007). 'What makes for effective labor representation on pension boards?' Labor Studies Journal, 32 (4): 382-410.

Weststar, J. and Verma, A. (2008). 'Just having it is not enough: labor's voice on pension boards'. In J. Quarter, I. Carmichael and S. Ryan (eds.), Pensions at Work: Socially Responsible Investment of Union-Based Pension Funds. Toronto: University of Toronto Press. pp. 42-69. 
Table 1

General Sample Characteristics Not Included in Regressions (see Table 3)

\begin{tabular}{|c|c|c|c|c|}
\hline \multicolumn{2}{|c|}{ Sample Characteristics $(\mathrm{N}=116)$} & Mean & Std Dev & Range \\
\hline Funds & $\begin{array}{l}\text { Number of board members } \\
\text { board structure } \\
\text { Single union (Multi) } \\
\text { Single employer (Multi) }\end{array}$ & $\begin{array}{l}10.4 \\
.47 \\
.52\end{array}$ & $\begin{array}{l}4.56 \\
.50 \\
.51\end{array}$ & $\begin{array}{l}3-33 \\
0-1 \\
0-1\end{array}$ \\
\hline Trustees & $\begin{array}{l}\text { Average age } \\
\text { French survey (English) } \\
\text { Education } \\
\quad \leq \text { High school } \\
\text { Apprenticeship/skills certificate } \\
\text { College/cegep } \\
\text { Undergraduate } \\
\text { Graduate } \\
\text { Postgraduate/professional } \\
\text { Appointment mechanism } \\
\text { Elected by membership } \\
\text { Appointed by union } \\
\text { Appointed by plan/board } \\
\text { Appointed by government } \\
\text { Other }\end{array}$ & $\begin{array}{l}44-49 \mathrm{yrs} \\
.25 \\
.18 \\
.09 \\
.20 \\
.21 \\
.16 \\
.16\end{array}$ & $\begin{array}{l}\mathrm{n} / \mathrm{a} \\
.43 \\
\\
.39 \\
.29 \\
.40 \\
.41 \\
.36 \\
.37\end{array}$ & $\begin{array}{l}<35-65+ \\
0-1 \\
0-1 \\
0-1 \\
0-1 \\
0-1 \\
0-1 \\
0-1\end{array}$ \\
\hline
\end{tabular}

Note. Where applicable alternative of dichotomous variables indicated by parentheses. 
Table 2

Factor Analysis of Contributions to Trustee Activities

\begin{tabular}{l|l|l}
\hline & Factor Loadings \\
\hline & Factor 1 (Investment) & Factor 2 (Procedural) \\
\hline Investment decisions & $\mathbf{. 8 5}$ & .02 \\
Fund performance & $\mathbf{. 9 1}$ & -.05 \\
Manager selection & $\mathbf{. 6 4}$ & .06 \\
Information sharing & -.01 & $\mathbf{. 8 5}$ \\
Rule interpretation & -.06 & $\mathbf{. 8 2}$ \\
Rule changing & .23 & $\mathbf{. 5 8}$ \\
\hline Cronbach Alpha & .84 & .82 \\
\hline
\end{tabular}

Note: Loadings associated with each factor are bolded in their respective column. Loadings of

0.5 or higher are considered strong loadings (Costello \& Osborne, 2007). 
Table 3

Descriptive Statistics for Dependent, Control, and Independent Variables

\begin{tabular}{|c|c|c|c|}
\hline$N=115$ & Mean & Std Dev & Range \\
\hline Investment-based & 1.97 & 1.03 & $0-4$ \\
\hline Procedure-based & 2.21 & .86 & $0-4$ \\
\hline Private sector (Public) & .34 & .48 & $0-1$ \\
\hline Fund assets & 5189 (mil) & 8843 & $2.26-43477(\mathrm{mil})$ \\
\hline Defined benefit plan (Other) & .81 & .39 & $0-1$ \\
\hline \multicolumn{4}{|l|}{ Jurisdiction (Federal) } \\
\hline $\mathrm{AB}$ & .06 & .24 & $0-1$ \\
\hline $\mathrm{BC}$ & .13 & .34 & $0-1$ \\
\hline MB & .04 & .20 & $0-1$ \\
\hline NB & .03 & .18 & $0-1$ \\
\hline NL & .02 & .13 & $0-1$ \\
\hline NS & .07 & .25 & $0-1$ \\
\hline ON & .16 & .37 & $0-1$ \\
\hline PEI & .02 & .13 & $0-1$ \\
\hline $\mathrm{QC}$ & .23 & .42 & $0-1$ \\
\hline SK & .07 & .25 & $0-1$ \\
\hline Previous exposure & .85 & .36 & $0-1$ \\
\hline Tenure $(<1 \mathrm{yr})$ & & & \\
\hline$\geq 1$ and $<4$ yrs & .27 & .45 & $0-1$ \\
\hline$\geq 4 \mathrm{yrs}$ & & & $0-1$ \\
\hline \multicolumn{4}{|l|}{ Training } \\
\hline Fiduciary responsibility & .83 & .38 & $0-1$ \\
\hline Pension law & .97 & .16 & $0-1$ \\
\hline $\begin{array}{l}\text { Capital markets/investment } \\
\text { strategy }\end{array}$ & .97 & .16 & $0-1$ \\
\hline Issues from a labor perspective & .90 & .30 & $0-1$ \\
\hline SRI/ETI & .91 & .28 & $0-1$ \\
\hline Actuarial valuation & .89 & .32 & $0-1$ \\
\hline Pension benefits & .92 & .27 & $0-1$ \\
\hline Percent union & 47.4 & 13.3 & $0-100$ \\
\hline Female & .23 & .42 & $0-1$ \\
\hline Visible minority & .05 & .22 & $0-1$ \\
\hline Report exec & 1.65 & 1.02 & $0-3$ \\
\hline Report members & 1.31 & 1.01 & $0-3$ \\
\hline Guidelines & .46 & .50 & $0-1$ \\
\hline Perceived exclusionary board dynamics & 1.15 & .83 & $0-3.5^{*}$ \\
\hline
\end{tabular}

Reference group in parentheses.

*Actual range 0-4; however, no respondents scored a 4. 
Table 4: Factors Associated with Contribution to Investment-Based Activities

\begin{tabular}{|c|c|c|c|c|c|c|}
\hline \multirow[t]{2}{*}{$\mathrm{N}=115$} & \multicolumn{3}{|c|}{ INVESTMENT-BASED CONTRIBUTION } & \multicolumn{3}{|c|}{ PROCEDURE-BASED CONTRIBUTION } \\
\hline & Step One & Step Two & Step Three & Step One & Step Two & Step Three \\
\hline Private sector (Public) & $\begin{array}{l}-.23 \\
(.21)\end{array}$ & $\begin{array}{l}-.27 \\
(.22)\end{array}$ & $\begin{array}{l}-.22 \\
(.19)\end{array}$ & $\begin{array}{l}.19 \\
(.19)\end{array}$ & $\begin{array}{l}-.29^{*} \\
(.17)\end{array}$ & $\begin{array}{l}-.27^{*} \\
(.16)\end{array}$ \\
\hline Fund assets (in millions of dollars) & $\begin{array}{l}-1.4 \\
(11.0)\end{array}$ & $\begin{array}{l}2.2 \\
(12.0) \\
\end{array}$ & $\begin{array}{l}1.1 \\
(11.0) \\
\end{array}$ & $\begin{array}{l}4.2 \\
(9.8) \\
\end{array}$ & $\begin{array}{l}-6.5 \\
(9.3) \\
\end{array}$ & $\begin{array}{l}-7.0 \\
(9.1) \\
\end{array}$ \\
\hline DB plan (Other) & $\begin{array}{l}-.57^{* *} \\
(.26)\end{array}$ & $\begin{array}{l}-.31 \\
(.27)\end{array}$ & $\begin{array}{l}-.29 \\
(.24)\end{array}$ & $\begin{array}{l}-.27 \\
(.23)\end{array}$ & $\begin{array}{l}-.28 \\
(.21)\end{array}$ & $\begin{array}{l}-.28 \\
(.21)\end{array}$ \\
\hline \multicolumn{7}{|l|}{ Jurisdiction (Federal) } \\
\hline $\mathrm{AB}$ & $\begin{array}{l}.32 \\
(.44) \\
\end{array}$ & $\begin{array}{l}.18 \\
(.49) \\
\end{array}$ & $\begin{array}{l}.32 \\
(.44) \\
\end{array}$ & $\begin{array}{l}-.07 \\
(.39) \\
\end{array}$ & $\begin{array}{l}-.02 \\
(.39)\end{array}$ & $\begin{array}{l}-.14 \\
(.38) \\
\end{array}$ \\
\hline $\mathrm{BC}$ & $\begin{array}{l}.48 \\
(.34) \\
\end{array}$ & $\begin{array}{l}.43 \\
(.36) \\
\end{array}$ & $\begin{array}{l}.48 \\
(.34) \\
\end{array}$ & $\begin{array}{l}.45 \\
(.30) \\
\end{array}$ & $\begin{array}{l}.38 \\
(.28) \\
\end{array}$ & $\begin{array}{l}.28 \\
(.28) \\
\end{array}$ \\
\hline $\mathrm{MB}$ & $\begin{array}{l}.30 \\
(.48) \\
\end{array}$ & $\begin{array}{l}.41 \\
(.50) \\
\end{array}$ & $\begin{array}{l}.30 \\
(.48) \\
\end{array}$ & $\begin{array}{l}-.03 \\
(.43) \\
\end{array}$ & $\begin{array}{l}.31 \\
(.39) \\
\end{array}$ & $\begin{array}{l}.18 \\
(.38) \\
\end{array}$ \\
\hline NB & $\begin{array}{l}.28 \\
(.54)\end{array}$ & $\begin{array}{l}.73 \\
(.58)\end{array}$ & $\begin{array}{l}.28 \\
(.54)\end{array}$ & $\begin{array}{l}-.38 \\
(.48)\end{array}$ & $\begin{array}{l}.01 \\
(.45)\end{array}$ & $\begin{array}{l}.03 \\
(.44)\end{array}$ \\
\hline NL & $\begin{array}{l}-.88 \\
(.72) \\
\end{array}$ & $\begin{array}{l}-1.34^{*} \\
(.74) \\
\end{array}$ & $\begin{array}{l}-.88 \\
(.72) \\
\end{array}$ & $\begin{array}{l}-.48 \\
(.64) \\
\end{array}$ & $\begin{array}{l}-.58 \\
(.58) \\
\end{array}$ & $\begin{array}{l}-.20 \\
(.58) \\
\end{array}$ \\
\hline NS & $\begin{array}{l}.03 \\
(.41) \\
\end{array}$ & $\begin{array}{l}.22 \\
(.41) \\
\end{array}$ & $\begin{array}{l}.03 \\
(.41) \\
\end{array}$ & $\begin{array}{l}.45 \\
(.36) \\
\end{array}$ & $\begin{array}{l}.22 \\
(.32) \\
\end{array}$ & $\begin{array}{l}.11 \\
(.31) \\
\end{array}$ \\
\hline $\mathrm{ON}$ & $\begin{array}{l}.12 \\
(33) \\
\end{array}$ & $\begin{array}{l}.12 \\
(.35) \\
\end{array}$ & $\begin{array}{l}.12 \\
(.33) \\
\end{array}$ & $\begin{array}{l}.32 \\
(.29) \\
\end{array}$ & $\begin{array}{l}.26 \\
(.27) \\
\end{array}$ & $\begin{array}{l}.30 \\
(.27)\end{array}$ \\
\hline PEI & $\begin{array}{l}-1.21^{*} \\
(.71)\end{array}$ & $\begin{array}{l}-.81 \\
(.74) \\
\end{array}$ & $\begin{array}{l}-1.21^{*} \\
(.71)\end{array}$ & $\begin{array}{l}-1.30^{* *} \\
(.64)\end{array}$ & $\begin{array}{l}-.62 \\
(.58) \\
\end{array}$ & $\begin{array}{l}-.53 \\
(.56) \\
\end{array}$ \\
\hline $\mathrm{QC}$ & $\begin{array}{l}-.46 \\
(.30)\end{array}$ & $\begin{array}{l}-.04 \\
(.32)\end{array}$ & $\begin{array}{l}-.46 \\
(.30)\end{array}$ & $\begin{array}{l}-.09 \\
(.27)\end{array}$ & $\begin{array}{l}.12 \\
(.25)\end{array}$ & $\begin{array}{l}.08 \\
(.25)\end{array}$ \\
\hline SK & $\begin{array}{l}1.29^{\text {*** }} \\
(.42)\end{array}$ & $\begin{array}{l}1.36^{\text {*** }} \\
(.45)\end{array}$ & $\begin{array}{l}1.29^{\text {**** }} \\
(.42)\end{array}$ & $\begin{array}{l}.40 \\
(.37) \\
\end{array}$ & $\begin{array}{l}.28 \\
(.35)\end{array}$ & $\begin{array}{l}.15 \\
(.34)\end{array}$ \\
\hline Previous exposure & & $\begin{array}{l}.34 \\
(.29)\end{array}$ & $\begin{array}{l}.35 \\
(.26)\end{array}$ & & $\begin{array}{l}.74^{* * *} \\
(.22)\end{array}$ & $\begin{array}{l}.75^{* * * *} \\
(.22)\end{array}$ \\
\hline \multicolumn{7}{|l|}{ Tenure $(<1 y r)$} \\
\hline$\geq 1$ and $<4$ yrs & & .08 & .03 & & .26 & .23 \\
\hline
\end{tabular}




\begin{tabular}{|c|c|c|c|c|c|c|}
\hline & & $(.28)$ & $(.25)$ & & $(.22)$ & $(.22)$ \\
\hline$\geq 4 \mathrm{yrs}$ & & $\begin{array}{l}.18 \\
(.27) \\
\end{array}$ & $\begin{array}{l}.12 \\
(.24)\end{array}$ & & $\begin{array}{l}.71^{* * *} \\
(.21)\end{array}$ & $\begin{array}{l}.69^{* * *} \\
(.20)\end{array}$ \\
\hline \multicolumn{7}{|l|}{ Training } \\
\hline Fiduciary responsibility & & $\begin{array}{l}-.06 \\
(.22)\end{array}$ & $\begin{array}{l}.12 \\
(.20)\end{array}$ & & $\begin{array}{l}.16 \\
(.17)\end{array}$ & $\begin{array}{l}.13 \\
(.17)\end{array}$ \\
\hline Pension law & & $\begin{array}{l}-.18 \\
(.27)\end{array}$ & $\begin{array}{l}-.06 \\
(.24)\end{array}$ & & $\begin{array}{l}-.22 \\
(.21)\end{array}$ & $\begin{array}{l}-.16 \\
(.20)\end{array}$ \\
\hline Capital markets/investment strategy & & $\begin{array}{l}-.01 \\
(.28)\end{array}$ & $\begin{array}{l}-.21 \\
(.25)\end{array}$ & & \begin{tabular}{|l|}
.33 \\
$(.22)$
\end{tabular} & $\begin{array}{l}.23 \\
.21)\end{array}$ \\
\hline Issues from a labor perspective & & $\begin{array}{l}-.41 \\
(.28)\end{array}$ & $\begin{array}{l}-.32 \\
(.25)\end{array}$ & & $\begin{array}{l}-.23 \\
(.22)\end{array}$ & $\begin{array}{l}.18 \\
(.22)\end{array}$ \\
\hline SRI/ETI & & $\begin{array}{l}-.53^{* *} \\
(.23)\end{array}$ & $\begin{array}{l}-.29 \\
(.21)\end{array}$ & & $\begin{array}{l}.14 \\
(.18)\end{array}$ & $\begin{array}{l}-.04 \\
(.18)\end{array}$ \\
\hline Actuarial valuation & & $\begin{array}{l}.06 \\
(.24)\end{array}$ & $\begin{array}{l}.08 \\
(.21)\end{array}$ & & $\begin{array}{l}.06 \\
(.19)\end{array}$ & $\begin{array}{l}.07 \\
(.18)\end{array}$ \\
\hline Pension benefits & & $\begin{array}{l}.14 \\
(.25)\end{array}$ & $\begin{array}{l}.39^{*} \\
(.23)\end{array}$ & & $\begin{array}{l}-.28 \\
(.20)\end{array}$ & $\begin{array}{l}-.16 \\
(.20)\end{array}$ \\
\hline Percent union & & $\begin{array}{l}.0144^{*} \\
(.0075)\end{array}$ & $\begin{array}{l}.0103 \\
(.0076)\end{array}$ & & \begin{tabular}{|l|}
.0065 \\
$(.0059)$ \\
\end{tabular} & $\begin{array}{l}.0042 \\
(.0059)\end{array}$ \\
\hline Female & & $\begin{array}{l}-.03 \\
(.25)\end{array}$ & $\begin{array}{l}-.13 \\
(.22)\end{array}$ & & $\begin{array}{l}.20 \\
(.19)\end{array}$ & $\begin{array}{l}.16 \\
(.19)\end{array}$ \\
\hline Visible minority & & $\begin{array}{l}-.86^{* *} \\
(.43)\end{array}$ & $\begin{array}{l}-.71^{*} \\
(.38)\end{array}$ & & $\begin{array}{l}-.31 \\
(.34)\end{array}$ & $\begin{array}{l}-.25 \\
(.33)\end{array}$ \\
\hline Report exec & & $\begin{array}{l}.13 \\
(.11)\end{array}$ & $\begin{array}{l}.10 \\
(.09)\end{array}$ & & $\begin{array}{l}.28^{* * *} \\
(.09)\end{array}$ & $\begin{array}{l}.27^{* * * *} \\
(.08)\end{array}$ \\
\hline Report members & & $\begin{array}{l}-.14 \\
(.11) \\
\end{array}$ & $\begin{array}{l}-.10 \\
(.10)\end{array}$ & & $\begin{array}{l}.06 \\
(.08) \\
\end{array}$ & $\begin{array}{l}-.04 \\
(.08) \\
\end{array}$ \\
\hline Guidelines & & $\begin{array}{l}-.03 \\
(.19)\end{array}$ & $\begin{array}{l}.01 \\
(.17)\end{array}$ & & \begin{tabular}{|l|}
-.17 \\
$(.15)$ \\
\end{tabular} & $\begin{array}{l}.15 \\
(.15)\end{array}$ \\
\hline Perceived exclusionary board dynamics & & & $\begin{array}{l}-.56^{* * *} \\
(.11)\end{array}$ & & & $\begin{array}{l}-.25^{* * *} \\
(.10)\end{array}$ \\
\hline Adj. $R^{2}$ & .16 & .24 & .40 & .05 & .34 & .38 \\
\hline$\Delta \mathrm{R}^{2}$ & $.25^{* * *}$ & $.18^{*}$ & $.12^{* * *}$ & .16 & $.35^{* * *}$ & $.04^{* * *}$ \\
\hline
\end{tabular}

${ }^{*},{ }^{* * *}$, and ${ }^{* * *}$ denotes statistical significance at the $.1, .05$, and .01 levels, respectively. Omitted reference group in italics; standard error in parentheses. 